\title{
INFLUENCE OF SELECTED SYNTHESIS GAS COMPONENT ON INTERNAL PARAMETERS OF COMBUSTION ENGINE
}

\author{
CHRÍBIK Andrej ${ }^{1}$, POLÓNI Marián ${ }^{1}$, MINÁRIK Matej ${ }^{1}$ \\ ${ }^{I}$ Slovak University of Technology in Bratislava Faculty of Mechanical Engineering, Institute of Transport \\ Technology and Engineering Design, Námestie slobody 17, 81231 Bratislava, Slovakia, \\ email:andrej.chribik@stuba.sk
}

\begin{abstract}
The paper deals with the influence of selected component of synthesis gas on internal parameters of combustion engine that is planned to be used in micro-cogeneration unit. The aim is to better understand the mechanism of combustion of carbon monoxide mixed with methane and as a follow-up to optimize the operation of the Lombardini LGW 702 engine on change of fuel composition. Generally, an increasing proportion of carbon monoxide in methane mixture leads to a decrease in engine performance (mean indicated pressure) and the hourly fuel consumption in each of the operating modes of the engine increases. With growing proportion of $\mathrm{CO}$ in mixture with $\mathrm{CH}_{4}$, the maximum pressure in the cylinder increases together with pressure rise rate up to approximately $10 \%$ vol. of $\mathrm{CH}_{4}$. With further increasing proportion of $\mathrm{CH}_{4}$, there is a significant decrease of the before-mentioned engine parameters. The optimum ignition angle for pure methane, or carbon monoxide, does not change significantly and it is about $27^{\circ}$ CA BTDC.
\end{abstract}

KEYWORDS: methane, carbon monoxide, spark ignition engine, combustion analysis

\section{Introduction}

Nowadays the effective use of mineral resources is at the forefront of interest of the general public. It is also the solution of the issue of energy security of mankind in the future, when conventional energy sources will gradually be depleted and will have to be replaced by new technologies to gain energy for sustainable growth. One of the classic sources of energy is natural gas, which has to be transported from the place of extraction [1] and subsequently it has to be delivered to the place of use.

An important source of energy is also municipal waste of which the energy is efficiently recovered. The recovery runs as gasification freeing synthesis gases, which are used to drive cogeneration units for combined heat and power generation. At present, basically all power units are turbocharged to increase overall efficiency [2]. It is an efficient recovery of the energy bonded in the waste, with a high overall efficiency (over 90\%). Depending on the method of production and the feedstock, the synthesis gas may have various composition [3, 4]. Before use the raw synthesis gas has to be purified from unwanted constituents (various tars, hydrogen sulphides, etc.) that may damage the internal combustion engine. Generally, the synthesis gas produced consists of methane, hydrogen, carbon monoxide and noncombustible gases (carbon dioxide and nitrogen).

The presented article deals with a partial study of the influence of carbon monoxide in a mixture with methane on internal parameters of combustion engines. The aim is to learn about the influence of carbon monoxide itself on the overall parameters and on the course of burning in the combustion chamber of the internal combustion engine that operates on synthesis gases. 
The following table (Tab. 1) shows the basic physical-chemical properties of a mixture of methane $\left(\mathrm{CH}_{4}\right)$ with carbon monoxide $(\mathrm{CO})$ in varying proportions of individual components. The properties of these mixtures were determined by calculation based on the input tabulated values of the constituent elements.

Tab. 1: Physical and chemical properties of mixture methane $\left(\mathrm{CH}_{4}\right)$ with carbon monoxide (CO), NTP $-20^{\circ} \mathrm{C}$ and $101325 \mathrm{~Pa}$

\begin{tabular}{|c|c|c|c|c|c|c|c|}
\hline Parameter & $\mathbf{C H}_{4} / \mathbf{C O}$ & $\begin{array}{c}\text { Molar } \\
\text { Mass }\end{array}$ & $\begin{array}{c}\text { Density } \\
(\mathbf{N T P})\end{array}$ & $\begin{array}{c}\text { Lower } \\
\text { Heating } \\
\text { Value }\end{array}$ & $\begin{array}{c}\text { Air to Fuel } \\
\text { Ratio }\end{array}$ & $\begin{array}{c}\text { Heating } \\
\text { Value } \\
\text { of } \\
\text { Mixture }\end{array}$ & $\begin{array}{c}\text { Fuel in } \\
\text { Air }\end{array}$ \\
\hline Unit & {$[\%$ vol. $]$} & {$\left[\mathrm{g} \cdot \mathrm{mol}^{-1}\right]$} & {$\left[\mathrm{kg} \cdot \mathrm{m}^{-3}\right]$} & {$\left[\mathrm{kJ} \cdot \mathrm{kg}^{-1}\right]$} & {$\left[{\left.\mathrm{kg} \cdot \mathrm{kg}^{-1}\right]}^{-1}\right.$} & {$\left[\mathrm{kJ} \cdot \mathrm{m}^{-3}\right]$} & {$[\%$ vol. $]$} \\
\hline $\mathbf{C H}_{4}$ & $100 / 0$ & 16.04 & 0.667 & 50012 & 17.12 & 3172 & 9.5 \\
\hline CH4CO25 & $75 / 25$ & 19.03 & 0.791 & 35329 & 11.73 & 3201 & 11.5 \\
\hline CH4CO50 & $50 / 50$ & 22.03 & 0.916 & 24638 & 7.80 & 3244 & 14.4 \\
\hline CH4CO75 & $25 / 75$ & 25.02 & 1.040 & 16501 & 4.81 & 3321 & 19.4 \\
\hline CO & $0 / 100$ & 28.01 & 1.165 & 10103 & 2.46 & 3473 & 29.5 \\
\hline
\end{tabular}

From the Tab. 1 it can be seen that increasing the proportion of carbon monoxide in the mixture with methane increases the molar mass, which is also related to the increasing density of the mixture, from the original value of $0.667 \mathrm{~kg} / \mathrm{m}^{3}$ to $1.165 \mathrm{~kg} / \mathrm{m}^{3}$. To produce a stoichiometric mixture of methane with air, $9.5 \%$ vol. of methane is needed; vice versa, to produce a stoichiometric mixture of carbon monoxide with air, up to $29.5 \%$ vol. of carbon monoxide is needed. By increasing the proportion of carbon monoxide in mixture with methane, the lower calorific value of the fuel decreases from 50.0 MJ / kg for methane to 10.1 MJ / kg for carbon monoxide. Conversely, the volumetric calorific value of the fuel-air mixture is more favourable when combusting carbon monoxide $\left(3473 \mathrm{~kJ} / \mathrm{m}^{3}\right)$ compared to methane $\left(3172 \mathrm{~kJ} / \mathrm{m}^{3}\right)$. Therefore, it would seem that a higher engine performance is achieved with $\mathrm{CO}$, since the stoichiometric mixture with air has a higher energy potential. Owing to the cylinder pressure, which is influenced by lower burned-gas volume production, as well as by the energy release rate itself, higher performance parameters are achieved in operation on methane.

\section{Experimental results}

The experiments were performed with an internal combustion engine that had been designed for a micro-cogeneration unit [5]. The combustion engine is a non-turbocharged Lombardini LGW 702 engine with basic parameters shown in the following table (Tab. 2).

Tab. 2: Basic parameters of the combustion engine Lombardini LGW 702

\begin{tabular}{|c|c|}
\hline Crankshaft throw angle $\left[{ }^{\circ}\right]$ & 360 \\
\hline Swept volume & 686 \\
\hline Bore/ Stroke & $75 / 77.6$ \\
\hline Compression ratio & $12.5: 1$ \\
\hline Valve gear/ Drive & OHC/Belt drive system \\
\hline Fuel & Natural gas (and alternative gases) \\
\hline Lubrication system & $\begin{array}{l}\text { Pressure circuit, full-flow filtration, } \\
\text { oil filling } 1.61\end{array}$ \\
\hline
\end{tabular}

The following figure (Fig.1) shows a scheme of the measuring bed for the internal combustion engine and the electric induction dynamometer MEZ Vsetín. A low-displacement 
internal combustion engine $\left(686 \mathrm{~cm}^{3}\right)$ is used to reduce the operating costs for experimental synthesis gases, as the operation has a high hourly consumption of these gases.

Various combinations of gases had been mixed from pressure bottles. The preparation of air-fuel mixture was performed by a diffuser mixer and the control of stoichiometric mixture was done by means of a feedback control unit. The optimal angle of ignition advance was set manually. All measurements were performed at full load. In order to determine the optimal ignition advance angles at the engine revolutions $1500 \mathrm{~min}^{-1}$, measurements of regulation characteristics were performed during operation on just methane alone, or just carbon monoxide. Subsequently, under the same number of revolutions, methane was gradually mixed to carbon monoxide, approximately $5 \mathrm{l} / \mathrm{min}$ of methane.

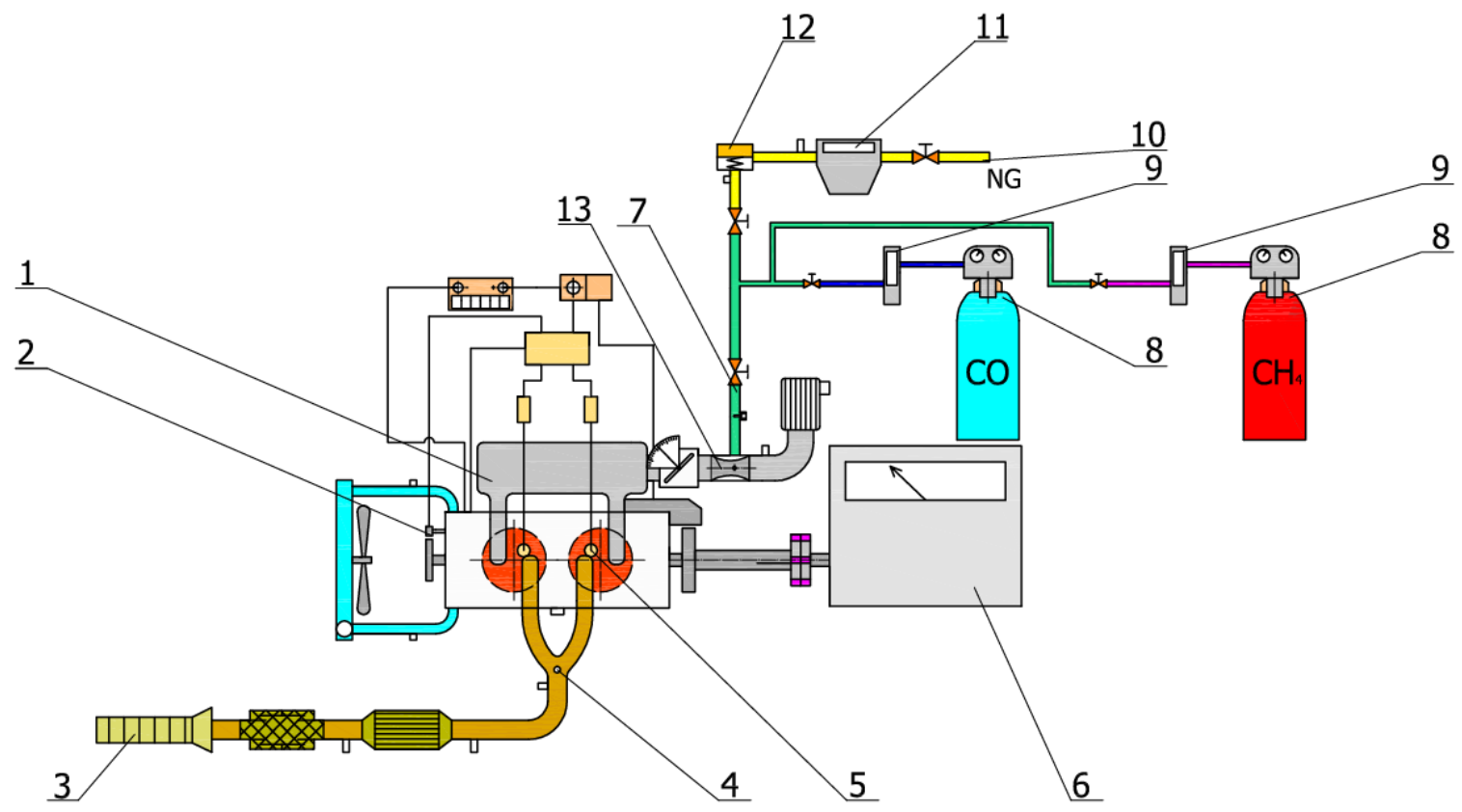

Fig. 1: The basic scheme of the combustion engine LGW 702 (1 - intake manifold, 2 position sensor of the crankshaft, 3 - exhaust system, 4 - exhaust temperature sensor, 5 - spark plug with integrated pressure sensor, 6 - dynamometer, 7 - mixture richness regulation, 8 pressure bottle of methane and carbon monoxide , 9 - mass flowmeter of gas, 10 - supply of natural gas, 11 - volumetric flow-meter of natural gas, 12 - zero pressure regulator, 13 - mixer with diffuser)

For the analysis of the combustion process, also the pressure courses in the combustion chamber of the engine were recorded. To serve this purpose, a measuring system consisting of an integrated piezoelectric sensor in the KISTLER 6117 BDC15 spark plug, a charge amplifier, and an A / D converter were used. In order to reduce the dynamic course of pressure to the absolute pressure in the cylinder, a piezoresistive pressure sensor was used that monitored the absolute pressure at the time of the suction stroke around the bottom dead centre. The crankshaft position was monitored by the sensor Kistler 2614A. $\mathrm{CO}$ and $\mathrm{CH}_{4}$ gases were measured using the Bronkhorst mass flowmeter and based on the $\lambda$ probe information, the control unit corrected the richness of the mixture using a stepper motor built into the fuel supply. In the Matlab programming environment, a program was developed to process data from the pressure sensors, the crankshaft position, and the moment of ignition timing.

The process of combustion in the combustion chamber of the engine was evaluated on the basis of single-zone-zero-dimensional thermodynamic model, [6,7]. The model was 
developed for a closed system, i.e. the intake and exhaust valves were closed, on the principle of energy conservation. The course of the release of heat from the fuel mixture was determined on the basis of analyzed course of pressure in the combustion chamber by Rassweiler-Withrow method. The method is based on the fact that the pressure increase in the combustion chamber comprises both the increase in combustion pressure and the increase in pressure, caused by changed volume as the piston moves in the cylinder (equation (1)). It is based on the general:

where:

$$
d U=d Q-d W+\sum_{i} h_{i} \cdot d m_{i}
$$

$d U$ - change of internal energy of matter in the system

$d Q$ - heat delivered to the system

$d W$ - the work produced by the system

hi.dmi - $i$-th component of enthalpy of mass flow across system boundaries.

The pressure measured continuously allowed for evaluation of uniformity of combustion engine running, which is characterized by the so-called coefficient of variation (COV). The coefficient of variation is calculated as the ratio of standard deviation to the arithmetic average of the parameter examined, thus:

$$
\operatorname{COV}=\frac{\sqrt{\frac{1}{n-1} \sum_{i=1}^{n} x_{i}-\bar{x}}}{\bar{x}} .100 \quad[\%]
$$

Where $\mathrm{n}$ is the total number of consecutive cycles, $\mathrm{x}_{\mathrm{i}}$ is the $\mathrm{i}$-th value of the tested parameter in a given cycle and and $\bar{x}$ is the average value of the tested parameter from a given number of cycles. The cycle variability has a significant impact on the overall life of the internal combustion engine, as well as on its performance parameters and related fuel consumption.

In the following figure (Fig. 2) introduces courses of pressure in the cylinder around of the top dead centre for the two-component fuel mixture $(\mathrm{CH} 4 \mathrm{CO})$ of $\mathrm{CO}$ and $\mathrm{CH}_{4}$. The lowest value of maximum pressure occurs while combusting carbon monoxide (4.7 MPa). Increasing $\mathrm{CH}_{4}$ by small amount in the mixture with $\mathrm{CO}$ (about $13.9 \%$ vol. $\mathrm{CH}_{4}$ ), there occurs a sudden and considerable increase in pressure $(7.1 \mathrm{MPa})$. The maximum pressure for combusted methane is $5.6 \mathrm{MPa}$. The position of maximum pressure after increasing $\mathrm{CH}_{4}$ up to $15 \%$ gradually approaches the top dead centre (TDC) and then, after further increase of $\mathrm{CH}_{4}$, it slightly diverges from the TDC. The coefficient of variation (COV) of maximum pressure for $\mathrm{CO}$ is $8.8 \%$ and for $\mathrm{CH}_{4}$ this value is $8.1 \%$. By gradual increase of $\mathrm{CH}_{4}$ in the mixture with $\mathrm{CO}$ the coefficient drops sharply to $3.4 \%$ at approximately $15 \%$ of present $\mathrm{CH}_{4}$ and then, under gradual increase of $\mathrm{CH}_{4}$, the coefficient rises up to the value for pure methane.

A similar pattern as maximum pressure can be noticed with pressure rise rate. When combusting pure carbon monoxide, this value is $0.139 \mathrm{MPa} / 1{ }^{\circ} \mathrm{CA}$ and increasing $\mathrm{CH}_{4}$ to about $8 \%$ vol. increases the pressure rise rate sharply to $0.326 \mathrm{MPa} / 1{ }^{\circ} \mathrm{CA}$. Subsequently, by further increasing $\mathrm{CH}_{4}$, the pressure rise rate progressively decreases to $0.191 \mathrm{MPa} /{ }^{\circ} \mathrm{CA}$ for pure methane.

The methane in the mixture with carbon monoxide will also influence the course of combustion. Figure (Fig.3) shows the mass fraction burned (MFB) of the fuel and the fuel combustion rate $(\mathrm{dMFB} / \mathrm{d} \alpha)$ as dependence on the angle of crankshaft rotation for various compositions of the $\mathrm{CH} 4 \mathrm{CO}$ mixture. The period between the start of ignition (SOI) and 
burning of $5 \%$ of carbon monoxide is approximately $20.6{ }^{\circ} \mathrm{CA}$, compared to burning methane, in which case that time is $19.9^{\circ} \mathrm{CA}$. A greater difference can be observed with the mixture containing $13.9 \% \mathrm{CH}_{4}$, in which case the period decreases to $14.6{ }^{\circ} \mathrm{CA}$. A similar pattern has been recorded with $50 \%$ of fuel burned, in which case heat $\left(363{ }^{\circ} \mathrm{CA}\right)$ is fastest released from fuel at $13.9 \%$ proportion of $\mathrm{CH}_{4}$ in the $\mathrm{CH} 4 \mathrm{CO}$ mixture. For $\mathrm{CO}$ combustion, the angle at which the $50 \%$ mass fraction has been burned is approximately $374{ }^{\circ} \mathrm{CA}$, or for methane it is $371{ }^{\circ} \mathrm{CA}$. The duration of the main combustion $(10 \%$ mass fraction burned -90 $\%$ mass fraction burned) is $30.8^{\circ} \mathrm{CA}$ for $\mathrm{CO}$, or $24.7^{\circ} \mathrm{CA}$ for methane. A considerably short burning period $\left(23.2{ }^{\circ} \mathrm{CA}\right)$ has been measured for the proportion of $13.9 \%$ vol. of $\mathrm{CH}_{4}$. The coefficient of variation (COV) for $5 \%$ of mass fraction burned is $0.36 \%$ for both $\mathrm{CO}$ and for $\mathrm{CH} 4$. The lowest $\mathrm{COV}$ value is for $13.9 \%$ proportion of $\mathrm{CH}_{4}$ and is $0.24 \%$. Greater differences in scattering have been recorded at the position in which $50 \%$ of the fuel has been burned. Specifically, for $\mathrm{CO}$ it is $0.68 \%$ and for $\mathrm{CH}_{4}$ it is $0.58 \%$. Once again, the lowest $\mathrm{COV}$ value $(0.41 \%)$ is at $13.9 \%$ proportion of $\mathrm{CH}_{4}$ in the mixture with $\mathrm{CO}$. The greatest differences in COV are recorded for fuel reduction (90\% MFB) when this value is for CO $1.10 \%$ and for $\mathrm{CH}_{4} 0.86 \%$. The slightest difference between the individual cycles in which 90 $\%$ fuel has been burned is found for the position $13.9 \%$ vol. of $\mathrm{CH}_{4}$. Its value is $0.29 \%$.

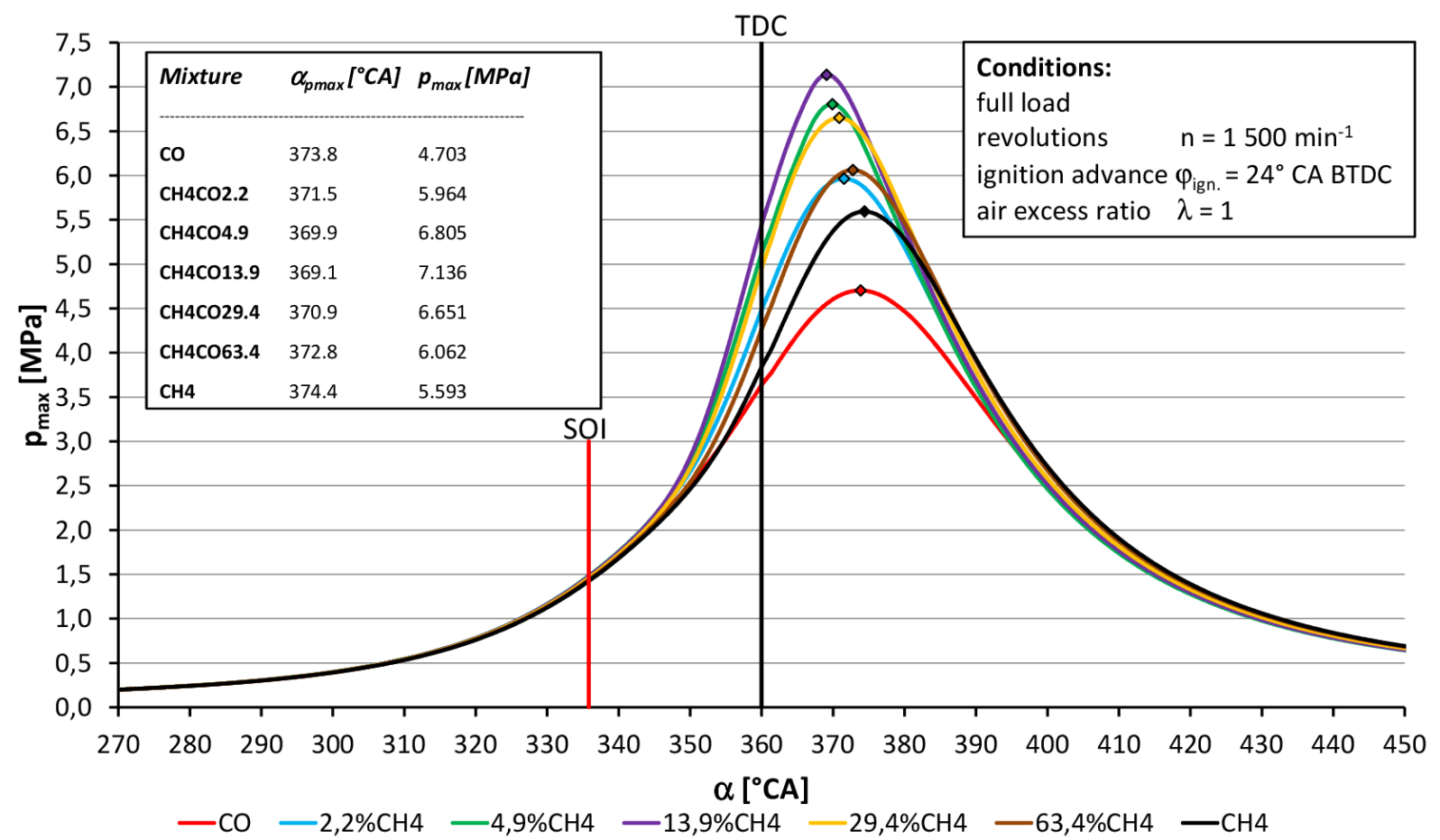

Fig. 2: Course of pressure in the combustion chamber as dependent on the crank angle, for various mixtures of carbon monoxide with methane (SOI - start of ignition,

TDC - top dead centre)

In general, the presence of a small amount (from 5 to $15 \%$ ) of $\mathrm{CH}_{4}$ in $\mathrm{CH} 4 \mathrm{CO}$ mixture significantly increases the rate of oxidation reactions. This is due to the $\mathrm{H}$-containing species enhancing the oxidation reactions of $\mathrm{CO}$ with $\mathrm{O}_{2}$ by providing $\mathrm{H}$-bearing radicals such as $\mathrm{HO}_{2}, \mathrm{H}$, and especially $\mathrm{OH}$ during their own oxidation reactions with oxygen, which accelerate the oxidation reaction rates of $\mathrm{CO}$ in air $[8,9]$.

The foregoing results indicate the need to optimize the ignition angle for each composition of mixture, even under constant operating conditions of the internal combustion engine. The following figure (Fig. 4) shows the fuel burn-up curves for different $\mathrm{CH} 4 \mathrm{CO}$ mixtures at optimum ignition angles, where the highest performance parameters are achieved. 


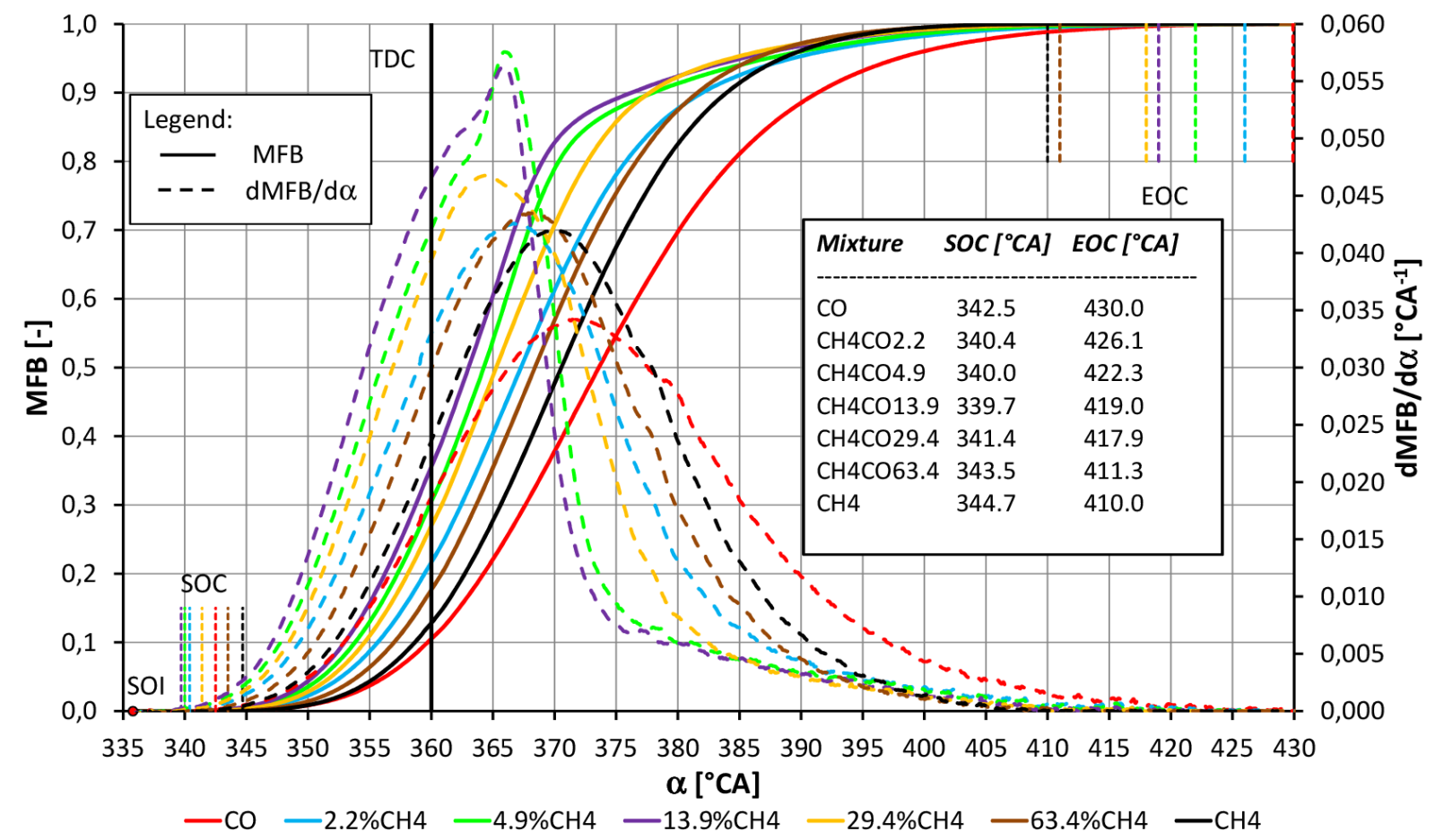

Fig 3: Course of burning of fuel as dependent on the crankshaft angle for various mixtures of $\mathrm{CH}_{4}$ and $\mathrm{CO}$ (SOI - Start of Ignition, SOC - Start of Combustion, EOC - End of Combustion)

In Fig.4 the main combustion period (10-90 MFB) for pure methane lasts $22.2^{\circ} \mathrm{CA}$ and for carbon monoxide it lasts $24{ }^{\circ} \mathrm{CA}$. The shortest main combustion period $\left(17{ }^{\circ} \mathrm{CA}\right)$ relates to operating on $\mathrm{CH} 4 \mathrm{CO}$ with $5 \%$ vol. of $\mathrm{CH}_{4}$. The ignition delay (from sparking to $5 \%$ of MFB) is the shortest when the internal combustion engine operates on $5 \%$ methane in mixture with $\mathrm{CO}$ and the value of delay is $15^{\circ} \mathrm{CA}$. For pure methane, this value is $22{ }^{\circ} \mathrm{CA}$, and for pure carbon monoxide it is $18^{\circ} \mathrm{CA}$.

\section{CONCLUSION}

For burning methane mixed with carbon monoxide, the following findings regarding the power and economic parameters, as well as parameters related to combustion of the mixture of $\mathrm{CH}_{4}$ and $\mathrm{CO}$ in the engine cylinder at $1500 \mathrm{~min}^{-1}$ can be summed up:

- by increasing the $\mathrm{CH}_{4}$ content in the mixture with $\mathrm{CO}$, the volumetric heating value of stoichiometric fuel-air mixture is reduced from $3473 \mathrm{~kJ} / \mathrm{m}^{3}$ for $\mathrm{CO}$ to $3172 \mathrm{~kJ} / \mathrm{m}^{3}$ for $\mathrm{CH}_{4}$,

- the performance parameters (indicated mean effective pressure) with a growing share of $\mathrm{CH}_{4}$ increase by about $5.5 \%$, from $0.87 \mathrm{MPa}$ for $\mathrm{CO}$ to $0.92 \mathrm{MPa}$ for $\mathrm{CH}_{4}$,

- with increasing $\mathrm{CH}_{4}$ there occurs a decrease in the hourly fuel consumption, the difference between pure $\mathrm{CO}$ and pure $\mathrm{CH}_{4}$ is approximately $82 \%$,

- increasing percentage of $\mathrm{CH}_{4}$ also leads to higher maximum pressure in the cylinder, from 4.7 MPa for carbon monoxide to 5.6 MPa for methane,

- increase in the pressure rise rate has been recorded after gradual addition of $\mathrm{CH}_{4}$ to the mixture, from the original value $0.139 \mathrm{MPa} / 1^{\circ} \mathrm{CA}$ for $\mathrm{CO}$ to $0.191 \mathrm{MPa} / 1^{\circ} \mathrm{CA}$ for $\mathrm{CH}_{4}$, 

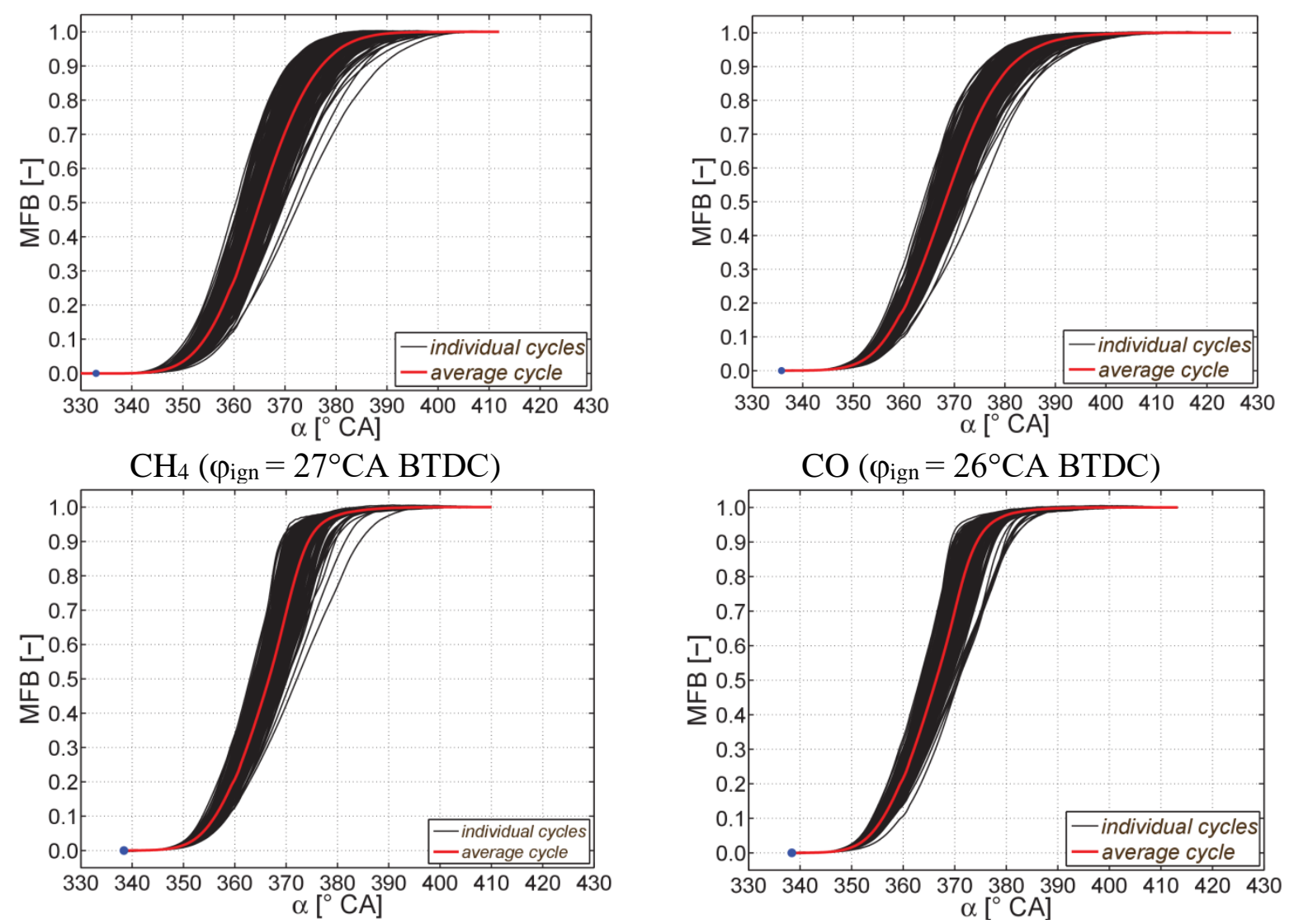

CH4CO_5\%vol. $\mathrm{CH}_{4}\left(\varphi_{\text {ign }}=22^{\circ} \mathrm{CA}\right.$ BTDC $)$
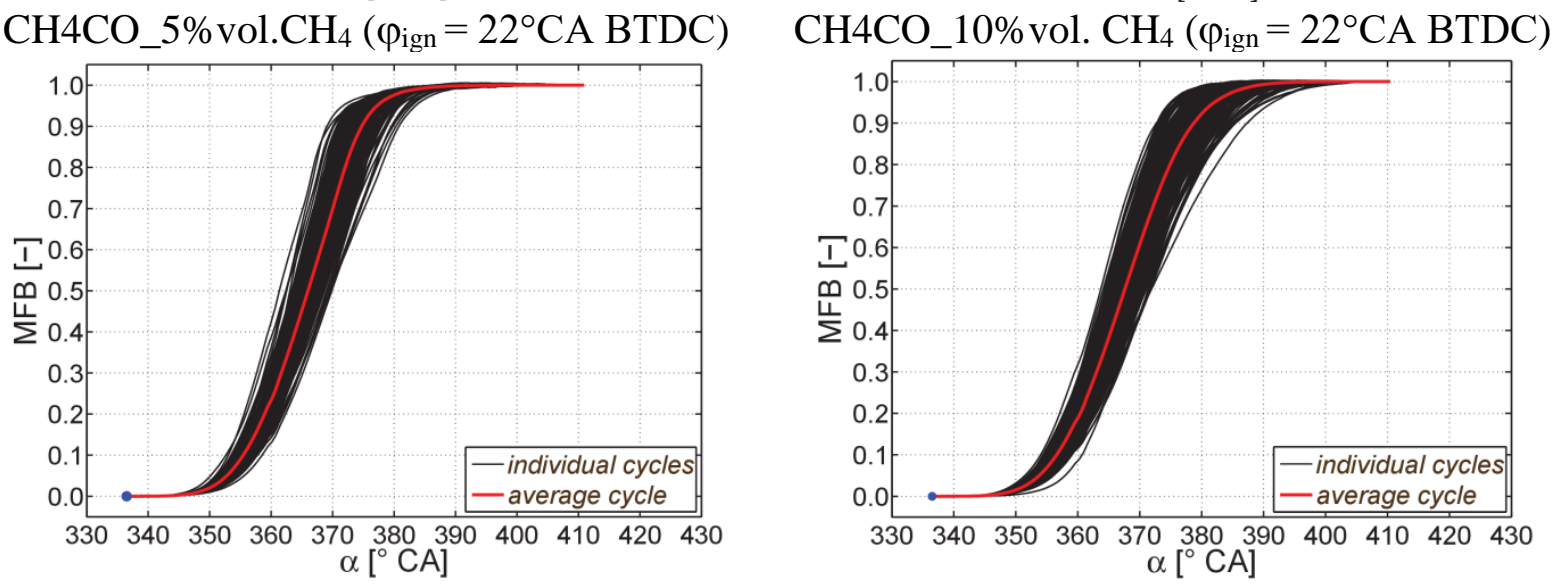

CH4CO_20\%vol. $\mathrm{CH}_{4}\left(\varphi_{\text {ign }}=23^{\circ} \mathrm{CA}\right.$ BTDC $)$

CH4CO_30\%vol. $\mathrm{CH}_{4}\left(\varphi_{\text {ign }}=24^{\circ} \mathrm{CA}\right.$ BTDC $)$

Fig 4: Mass fraction burnt (MFB) dependent on the crankshaft angle $(\alpha)$ (Conditions: optimum ignition angle, load $\alpha_{\text {throttle }}=100 \%$, air excess ratio $\lambda=1$, revolutions $\mathrm{n}=1500 \mathrm{~min}^{-1}$ )

- with a small amount of methane (around 5 to $15 \%$ vol.) in a mixture with carbon monoxide, the mixture is significantly faster burned, which is also demonstrated by maximum pressure in the cylinder $(7.1 \mathrm{MPa})$ or pressure rise rate $\left(0.326 \mathrm{MPa} / 1^{\circ} \mathrm{CA}\right)$. This proportion of $\mathrm{CH}_{4}$ also leads to a more uniform running of the engine in terms of the coefficient of variation for the monitored internal engine parameters,

- conclusive results show that a greater proportion of $\mathrm{CH}_{4}$ than $\mathrm{CO}$ in synthesis gases suits better to achieving higher power and less fuel consumption. 


\section{ACKNOWLEDGEMENT}

This work was supported by the Slovak Research and Development Agency under Contracts-No. APVV-17-0006, APVV-0015-12 and Contract-No. APVV-18-0023, and was also supported by the Slovak Scientific Grant Agency under the Contracts-No. VEGA 1/0301/17 and KEGA 026STU-4/2018.

\section{REFERENCES}

[1] Poberezhny, L., Hrytsanchuk, A., Okipnyii, I., Poberezhna, L., Stanetsky, A., Fedchyshyn, N. „Minimizing Losses During Natural Gas Transportation“, Strojnícky časopis - Journal of Mechanical Engineering 69 (1), pp. 97 - 108, 2019. DOI: 10.2478/scjme-2019-0008

[2] Vishwakarma, N., Renuke, A., Phalle V. M. „Effect of Tapered Interference Fit between Impeller and Shaft in Turbo Machines“, Strojnícky časopis - Journal of Mechanical Engineering 68 (3), pp. 25 - 32, 2018. DOI: 10.2478/scjme-2018-0024

[3] Ahmed, I. I., Gupta, A. K. "Pyrolysis and gasification of food waste: Syngas characteristics and char gasification kinetics”, Applied Energy 87(1), pp. 101 - 108, 2010. DOI: 10.1016/j.apenergy.2009.08.032

[4] Kapilan, K., Jullya, N. "Studies on Improvement of Performance of Compression Ignition Engine Fuelled with Mixture of Honge Biodiesel and Tire Pyrolysis Oil" Strojnícky časopis - Journal of Mechanical Engineering 68 (1), pp. 15 - 24, 2018. DOI: 10.2478/scjme-2018-0002

[5] Chríbik, A., Polóni, M., Lach, J., Ragan, B. "Utilization of synthesis gases in combustion engine", KOKA 2015, Bratislava, pp. 229 - 238, 2015. ISBN 978-80-2274424-9

[6] Puškár, M., Brestovič, T., Jasminová, N. "Numerical simulation and experimental analysis of acoustic wave influences on brake mean effective pressure in thrust-ejector inlet pipe of combustion engine", International Journal of Vehicle Design 67 (1), pp. 63 - 76, 2015. DOI: https://doi.org/10.1504/ijvd.2015.066479

[7] Puškár, M., Kopas, M. "System based on thermal control of the HCCI technology developed for reduction of the vehicle NOX emissions in order to fulfil the future standard Euro 7", Science of the Total Environment 643, pp. 674 - 680, 2018. DOI: 10.1016/j.scitotenv.2018.06.082

[8] Li, H., Karim, G. A., Sohrabi, A. "An Experimental and Numerical Investigation of Spark Ignition Engine Operation on $\mathrm{H} 2, \mathrm{CO}, \mathrm{CH} 4$, and Their Mixtures", Journal of Engineering for Gas Turbines and Power 132, pp. 8. 2009. ISSN 0742-4795

[9] Li, H., Karim, G. A. "Experimental investigation of the knock and combustion characteristics of $\mathrm{CH} 4, \mathrm{H} 2, \mathrm{CO}$, and some of their mixtures", Proceedings of the Institution of Mechanical Engineers, Part A: Journal of Power and Energy 220, pp. 459 - 471, 2006. ISSN 0957-6509 